\title{
International Recognition and Its Implications for the Statehood*
}

\author{
Ieva Vezbergaite \\ Sabancı University, İstanbul, Turkey
}

\begin{abstract}
State recognition is perhaps one of the oldest practices in international relations. While recognition is one of the most vexed concepts in international law that has been extensively analyzed and debated, the topic has been traditionally understudied in International Relations (IR). IR scholars find the recognition as tedious topic, because these scholars see states as self-constituted and self-contained bodies-states are a matter of fact and thus state sovereignty (statehood) is a matter of fact. In this paper, we suggest that relationship between recognition and statehood is more complicated than current legal or IR theories hold and we submit that international recognition is one of the constituents of statehood. This proposition challenges to current theoretical models, as it suggests that statehood is actually a creation of international politics rather than a mere fact on ground. The paper reviews the legal and IR perspectives on recognition of states, including reasons for granting recognition/non-recognition and consequences of recognition to the statehood. We develop critique over the current approach of IR and legal theories. While legal theorists painstakingly attempt to isolate "law of recognition" from politics and unsuccessfully attempt to build the normative framework that is universally applicable for all situations, the IR theories fail to grasp the process of state-birth and the role of recognition to the statehood of an entity. We submit that recognition is a political act that has hardly to do with any legal norms. However, recognition is a crucial tool in the system of states where the recognition of an entity by critical mass of states results into that entity's entry into the system as a state.
\end{abstract}

Keywords: recognition, statehood, international law, international relations

\section{Introduction}

State recognition is perhaps one of the oldest practices in international relations. While recognition is one of the most vexed concepts in international law that has been extensively analyzed and causes decades-long scholarly debates over legal consequences of recognition to the sovereignty of a state, the topic has been traditionally understudied in International Relations (IR) discipline and few IR scholars have deemed it worthy of examination (Ker-Lindsay, 2015; Kinne 2014). International Relations scholars find the recognition (as a phenomenon) as tedious topic and the research would rather explore what were the consequences of recognition to i.e. regional stability, international security, etc. This is mainly because IR scholars see states as self-constituted and self-contained bodies - states are a matter of fact and thus state sovereignty (statehood) is a matter of fact.

In this paper we suggest that relationship between recognition and statehood is more complicated than current legal or IR theories hold and we submit that international recognition is one of the constituents of

\footnotetext{
* The research of this work was supported by the graduate scholarship programme of Scientific and Technological Research Council of Turkey (TÜBİTAK).

Ieva Vezbergaite, Ph.D. candidate, Faculty of Arts and Social Sciences, Sabancı University.
} 
statehood. This proposition challenges to current theoretical models, as it suggests that statehood is actually a creation of international politics rather than a mere fact on ground.

The paper reviews the legal and IR perspectives on recognition of states, including reasons for granting recognition/non-recognition and consequences of recognition to the statehood. We develop critique over the current approach of IR and legal theories. While legal theorists painstakingly attempt to isolate "law of recognition" from politics and unsuccessfully attempt to build the normative framework that is universally applicable for all situations, the IR theories fail to grasp the process of state-birth and the role of recognition to the statehood of an entity.

We submit that recognition is a political act that has hardly to do with any legal norms. However, recognition is a crucial tool in the system of states where the recognition of an entity by critical mass of states results into that entity's entry into the system as a state.

\section{Recognition in Law and International Relations}

In the nowadays world where there are established states with defined boundaries and no terra nulius, secession from "parent" state becomes the dominant form of state creation. The "parent" state refers to polities that have international legal recognition (Özpek, 2014). The newly emerged entities claiming statehood pose questions of recognition for other existing sovereign states. Often those newly emerged entities are referred as de facto states and as Özpek (2014) clearly points out, the de facto states are political authorities functioning within certain territory, but lacking international legal recognition.

Recognition is approached differently in international law and international relations, but both can offer an explanation when entities become states and what is the impact of recognition to the statehood.

\section{Recognition From a Legal Perspective}

Legal scholars hold that recognition, although heavily influenced by international politics, is an institution of international law. The entire sub-discipline called "Law of Recognition" is presumed to regulate the rights and duties of existing sovereign states towards the entity that claims to be a state and seeks to obtain international legal personality. There are two main theories-constitutive and declaratory-that explain statehood and consequences of recognition.

The constitutive theory grants recognition an important and powerful role in the international order by contending that statehood is conferred by the act of recognition by other states (Watson, 2008, p. 288). The difficult and complex question of statehood is reduced to the more pragmatic question of whether the entity has been recognized by other states. Recognition by other states is thus a conditio sine qua non for statehood (Ryngaert \& Sobrie, 2011). An entity becomes a state only when it is recognized as such by the existing states. Therefore, the recognition of a claimant entity as a state constitutes a state (Dugard \& Raič, 2006, p. 97). The constitutive theory seems to reflect state practice in that claimant entities only receive international rights and duties when they get recognized by other states (Worster, 2009, p. 131).

The constitutive theory has some serious drawbacks. "No qualifications or legal criteria exist under the constitutive theory for recognition, and unrecognized states would not enjoy the international legal personality of statehood" (Watson, 2008, p. 288). The weakness of this legal theory becomes salient when an entity has been recognized only by a part of the community of existing states. The theory cannot reply to a question to how many recognizing states are needed before an entity transforms into a state; and secondly, it is unclear 
whether the decision to recognize should be based on facts, norms, geopolitical considerations, or a combination of factors (Ryngaert \& Sobrie, 2011).

It is also noteworthy to mention that the critique on constitutive theory is based on general assumptions (by legalists) that statehood is not a subjective (relative), but objective. According to legalistic point of view, constitutive theory seems incapable to prove that statehood of claimant is not relative to political will of existing states (Worster, 2009). The legal theory becomes self-annihilating as it makes the state subject to the politics of other states, thus denying any legalism. The proponents of this theory could rebut the latter criticism claiming that instead of politics of unlimited state discretion, states in fact are limited to certain international norms in recognizing other states.

As an alternative, the declaratory theory contends that statehood, and thus international legal personality, arises independent of recognition when certain objective criteria of statehood are met by an entity (Ryngaert \& Sobrie, 2011). Therefore the creation of a state is a simple fact that is acknowledged (declared) by the recognizing states. The necessary criteria for statehood are most authoritatively defined in the Montevideo Convention of $1933^{1}$ that is commonly accepted as customary international law: "The state as a person of international law should possess the following qualifications: (1) a permanent population; (2) a defined territory; (3) government; and (4) capacity to enter into relations with the other states. In addition, the convention explicitly confirms declaratory theory: "The political existence of the state is independent of recognition by the other states".

According to the declaratory theory, then, statehood is fully determined by a set of factual conditionsonce an entity fulfills these criteria, it is a state. Recognition is nothing more than an official confirmation of a factual situation - a retroactive act that traces back to the moment at which the factual criteria were fulfilled and the entity became a state (Ryngaert \& Sobrie, 2011). Recognition does not affect statehood as such or a state's international rights and obligations - objective condition of statehood is independent of recognition (Ker-Lindsay, 2015). Recognition is a formality of very specific kind: a prerequisite for establishing diplomatic ties (Fabry, 2010). Currently, the declaratory theory is the dominant theory in international law scholarship. As Ryngaert and Sobrie (2011) puts it: "important aspect of its success lies in the fact that it deprives states of the prerogative of deciding on statehood based on political arbitrariness, in favor of objective legal norms" (p. 470).

Yet declaratory theory also suffers from criticisms, primarily due to very different facts on ground where one can find de jure recognized states that are hardly meeting the objective criteria of statehood (e.g. "failed states) and at the same time there are de facto states seeming to fulfill the aforementioned criteria. Moreover, as Vidmar (2009) points out, if declaratory theory holds, there would be virtually no consequences of non recognition, yet this is not the case with de facto states (p. 828).

In conclusion, the main difference between the two theories is the disagreement whether recognition is an essential requirement for statehood or whether the recognition is rather a confirmation of a pre-existing factual situation (Ryngaert \& Sobrie, 2011). According to the constitutive theory the entity becomes a state after the formal recognition, but according to the declaratory theory the entity becomes a state regardless the formal act of recognition when it meets factual requirements. However, both theories cannot evade the fact that is ultimately up to each state's executive branch to make decision whether the circumstances postulated by the

\footnotetext{
${ }^{1}$ Montevideo Convention on the Rights and Duties of States in 1933.
} 
norms have been satisfied and, in addition, to take into account pertinent political considerations, e.g. consequences for relations with the "parent" state.

\section{Deficiencies in The Legalistic View}

The declaratory theory has remained the dominant mode of conceiving recognition in legal scholarship despite the fact that such countries like Bosnia and Herzegovina, Croatia, or Moldova, similarly to a number of previous colonies declaring independence, have plainly not met the criteria postulated by the theory or have been considered as states by international society prior to their recognition (Fabry, 2010). Despite the declaratory school's success to "isolate" the law from international politics in theoretical plane, it seems that the theory has been increasingly disconnected by international practice.

If satisfaction of objective criteria results in statehood, why do entities without widespread international recognition fail to act as states in international system? Non-recognized existence has historically led to a range of adverse consequences for such entities. Entities without widespread recognition are unable to carry out normal diplomatic and economic relations with other states, unable to enter international institutions or cooperation agreements, it has no treaty authority on state matters and cannot exploit its natural resources, its domestic laws are not considered binding by another states (Coggins, 2011). The most serious consequence of non-recognition is that those who find themselves in this position are legally exposed to being forcibly displaced from the territory they claim and control by the state actually recognized as sovereign in that territory by other states (Fabry, 2010).

Although recognition is exclusively studied by legal scholars through the prism of the two legal theories without systematic research on actual state practice, a disconnection between theory and practice suggest that the legal theories have assumed a "theological" role as a body of thought with its own validity (Fabry, 2010). The legal theories have become detached from state conduct and acquired a life of their own.

Legal scholarship admits that the "body of international legal rules governing the process of state recognition finds itself in an existential crisis" (Ryngaert \& Sobrie, 2011) and feels the "need to bring back some consistency in the practice of state recognition" (Ryngaert \& Sobrie, 2011). The legal scholarship anxiety about losing "law of recognition" to politics can be accurately described by Worster's (2009) sentence: “There is a need for the law to reflect facts and any other conclusion results in the assignment of recognition to the purely political process rather than a justiciable rights-based process" (p. 120).

Due to deficiency of classic constitutive and declaratory theories, the legal scholars attempt to synthesize both of them (although unsuccessfully) or simply create a new "theological" theories providing additional normative frameworks for recognition, such as duty of non-recognition (Shaw, 2008, p. 468), requirement for new entity to comply with principle of self-determination; meet human rights, rule of law standards ${ }^{2}$; norm of non-recognition of unilateral secession (Roseberry, 2013; Fabry, 2012); sanction theory of recognition (Berlin, 2009), Manhattan school recognition theory (Downer, 2013), etc. Fabry (2010) refers to such legal scholars as "imposing their own unsubstantiated theories on a record of practice". The competing legal theories and their failings demonstrate that a state does not have any normative content per se, but rather, that the rules of recognition are legal vehicles for political choices (Worster, 2009).

We submit that the legal theory cannot accurately account for statehood and role of recognition due to the

\footnotetext{
${ }^{2}$ European Community Declaration on the Guidelines on the Recognition of New States in Eastern Europe and in the Soviet Union, December 16, 1991.
} 
flawed assumptions that (1) international law has a role as an outer limit on state discretion; (2) act of recognition by a state is guided by a normative framework; and (3) statehood is an absolute. In fact, the states use very limited legal discourse while recognizing entities as states. Moreover, factual Montevideo requirements are almost entirely absent in that legal discourse. The political considerations are primary in the recognition process and political, rarely legal, factors determine whether an entity will be recognized by a state. Instead of searching for ideal framework for recognition free of politics, the political processes must be analyzed.

\section{Recognition from IR Perspective}

Despite recognition's reputation as one of the most politicized and challenging phenomena in international law, international relations theorists have neither thought of it in broader theoretical terms nor inquired whether it may be an important institution in its own right (Fabry, 2010). International relations discipline finds recognition as tedious topic and the IR research would rather explore what were the consequences of recognition to i.e. regional stability, international security, etc. This is mainly because IR scholars see states as self-constituted and self-contained bodies - states are a matter of fact and thus state sovereignty is a matter of fact.

In IR, the main attribute of states is sovereignty. Sovereignty embodies the statehood. Sovereignty has two elements: internal (domestic) and external. Internally, sovereignty defines the ultimate or highest authority within a state. Internal sovereignty requires effective control over the territory claimed by the state. In absence of such control, there can be no ultimate authority and, thus, no sovereign. Internal sovereignty was understood to be prerequisite for recognition by the international community. Externally, sovereignty implies relationship of formal equality among the states in the anarchical international system (Lake, 2003). The absence of external sovereignty - international recognition — is what defines de facto states and distinguish them from de jure states (Broers, 2014).

IR theory assumes that conflicts over internal sovereignty are settled prior to state birth (Coggins, 2011). Westphalian paradigm describes state as having monopoly of using force within a given territory - effective authority. For systemic constructivism state has qualities of an institutional-legal order, claiming a monopoly on the legitimate use of organized violence, organization with sovereignty, territory (Wendt, 1999, p. 202). For IR theorists, domestic (internal) sovereignty shows statehood. The recognition of a state indicates that the entity concerned possesses the characteristics of sovereign statehood, and hence exists as such, rather than helps to bring it into existence (Fabry, 2010). State sovereignty is a factual matter and it cannot, once obtained, be affected by anything which is said by outsiders (Fabry, 2010).

Major systemic IR theories hold that statehood is exogenous. Sovereignty is a fixed and exogenous attribute of states (Lake, 2003) of the international system. States either exist or do not, and how they come to be is presumed to be relatively unproblematic. Although foreign states can play a role in maintaining a state's existence (by way of alliances or collective security arrangements) or they can be of critical importance even in launching new states, IR theorists hold that these eventualities are contingent to, but not constitutive of, statehood (Fabry, 2010).

\section{Deficiencies in IR Perspective}

Unfortunately, the major paradigms' consensus about the state's defining features provides few insights 
into state birth. IR theories suggest that the state's essence lies in its internal composition and authority (Coggins, 2011). Such overlook over the birth of states by IR theory is misleading. If the internal sovereignty is the defining characteristic of the state, then there is little perceptible difference between state and non-state entities - there are states that actually do not hold effective authority over their territory and hardly meet the Montevideo requirements while certain non-recognized entities have much better claim of satisfying statehood criteria. Moreover, disagreements over the sovereign members of the international community are common (Kosovo and Palestine are notable examples) and political wrangling among powerful states frequently determines when and whether aspiring system members will succeed in becoming new states (Coggins, 2011).

We argue that statehood is relative and that external (international) politics, not only the facts on the ground (or, say, domestic politics), but also determine the state birth. Effective authority alone is insufficient. Many secessionist entities or other independence movements are not successful in becoming states if they cannot secure widespread international recognition by existing members of international system. As Boers (2014) rightly points out, having waged wars for sovereign authority the de facto states continue to seek international recognition as "statehood remains top prize" for such entities (p. 146). It is not the domestic level conflict over sovereignty, but international politics that ultimately determine which aspiring system members will succeed in becoming new states (Coggins, 2011).

From rationalist point of view, international politics of recognition by self-interested states can potentially explain why newly accepted (recognized) states do not conform to scholarly or legal characterizations of the state and why those entities that meet the criteria are not considered as states. According to a realist school, a pursuit of national interest is the main goal and motivation of states in making foreign policy (Özpek, 2014, p. 595). States serve their own interests in the international system by principle of self-help due to absence of any authority above them. By pursuing self-interest states try to acquire power to secure themselves and ensure their survival in the system.

One potential motive behind recognition of a new state is pursuit of external security. States use recognition strategically to strengthen or protect themselves and to weaken their enemies. As virtually all world territory is divided by existing states, a birth of new state is most likely to occur due to internal contestation of sovereignty when there is internal secessionist challenge to an existing state. Pursuing self-interest, a state is more likely to recognize those who weaken its enemies and are less likely to recognize those who weaken their friends (Coggins, 2011).

A second potential influence on recognition behavior could be domestic insecurity. If the state has secessionist challengers at home, recognizing foreign secessionists might compromise its own domestic survival because secessionist challengers may interpret such recognition as a signal in support of separatism's legitimacy. Therefore a state that has internal secessionist challengers is less likely to recognize others (Coggins, 2011).

Coordination in recognition can be another possible explanation. The Great Power rationally may prefer coordinated recognition to maintain its power and security and to maintain international stability. If the Great Powers recognition is strategically coordinated, recognition proceeds quickly when the Great Power's interests align in favor of a state's emergence. For less powerful existing states, coordinated recognitions potential costs are lower. Moreover, the increasing number of recognitions followed by the Great Power's recognition would reach a critical mass for an entity to be regarded as a state. There have been multiple instances of joint and coordinated recognition or non-recognition orchestrated by Great Powers, including decisions of international 
organizations such as the League of Nations and the United Nations binding on its members (Fabry, 2010).

Based on above described approach, the international recognition makes an entity state and international politics motivate existing states decision to accept new members in international system. New states emerge when they are widely recognized as legitimate by established members. Recognition provides members entry into organizations and permits behaviors exclusively reserved for states. Not every member needs to recognize an aspiring member before it is considered as a state, but a critical mass must do so (Coggins, 2011).

Such approach holds important theoretical consequences. The state birth is instance of the second image reversed (Gourevitch, 1978), wherein system-level factors not only affect states' internal organization, but also determine the birth of new states in the international system. Such approach is also consistent with the English school tradition of realism as international system is society of states (Bull, 1977). Nonetheless, English school theorists contend that states and their mutual recognition constitute a society of states but that society is not constitutive of its new members (Fabry, 2010). Our approach goes further to claim that recognition is one of the constituents of statehood. Recognition is an indispensable precondition for entity's status as a sovereign state in international relations (Fabry, 2010). Although this approach might be interpreted as confirming the constitutive theory of recognition in international law, it is misleading interpretation. Constitutive theory of law still holds on assumption that there is absolute concept of state and that recognition occurs as a result of existing states' compliance with norms. Our approach in general challenges idea that any normative framework exists to accord statehood. International norms play little, if any, role in the process of recognition. Rather the process is governed merely by power politics of self-interested states pursuing their survival interests and emergence of new states is a result of such politics.

\section{Conclusion}

International recognition of states is not a result of compliance or violation of international norms. The so-called "law of recognition" developed by legal theorists have assumed a 'theological' role as a body of thought with its own validity. Both constitutive and declaratory theories are detached from state conduct in international relations. Although IR theories may acknowledge some role of international law in international politics, in this case, the recognition behavior of states has hardly anything to do with norms. Instead, the recognition should be analyzed from IR perspective looking for explanations of certain state behavior.

It is too simplistic to treat statehood and recognition as different phenomena (Wilson, 2009) both in international law and IR For IR theory, recognition is rather arid topic. Recognition of a state simply indicates that the entity concerned possesses the characteristics of sovereign statehood and recognition per se does not deserve any attention. This happens because IR scholars see states as self-constituted and self-contained bodies - states are a matter of fact and thus state sovereignty is a matter of fact. However, the mainstream IR theory overlooks the birth of states by assuming that conflicts over internal sovereignty are settled prior to state birth. Granting recognition to a claimant entity is crucial to state birth - in fact, it is more likely that recognition will constitute state birth than a factual acquisition of internal sovereignty (e.g. most of states emerging from decolonization). The statehood of the entity is not solely a matter of fact, but actually the granting recognition to entity is one of constitutive factors of statehood.

From realist point of view, the recognition of aspiring states as new members of international system is actually power politics of already existing states-members of international system. If recognition or non-recognition of secessionists furthers the self-interests of existing state, this state will act accordingly 
without any normative considerations or factual evaluations. The primary concerns of a recognition behavior are external security and domestic insecurity of an existing state. The Great Power will also coordinate recognition behavior to maintain its position in international system or improve it. The international politics determine whether the secessionist entity will become a sovereign state in the international system. Thus the recognition remains a crucial tool in the system of states where the recognition of an entity by critical mass of states results into that entity's entry into the system as a state.

\section{References}

Berlin, A. (2009). Recognition as sanction: Using international recognition of new states to deter, punish, and contain bad actors. University of Pennsylvania Journal of International Law, 31(2), 531-592.

Broers, L. (2014). Mirrors to the world: The claims to legitimacy and international recognition of de facto States in the South Caucasus Brown. Journal of World Affairs, 20(2),145-159.

Bull, H. (1977). The anarchical society: A study of order in world politics. London: Macmillan.

Coggins, B. (2011). Friends in high places: International politics and the emergence of states from secessionism. International Organization, 6(3), 433-467.

Downer, J. (2013). Towards a declaratory school of government recognition. Vanderbilt Journal of Transnational Law, 46(2), 581-611.

Dugard, J., \& Raič, D. (2006). The role of recognition in the law and practice of secession. In M. G. Kohen (Eds.), Secession: International Law Perspectives (pp. 97-137). Cambridge University Press

Fabry, M. (2010). Recognizing states: International society and the establishment of new states since 1776. Oxford University Press

Fabry, M. (2012). The contemporary practice of state recognition: Kosovo, South Ossetia, Abkhazia, and their aftermath. Nationalities Papers, 40(5), 661-676.

Gourevitch, P. (1978). The second image reversed: The international sources of domestic politics. International Organization, 32(4), 881-912.

Ker-Lindsay, J. (2015). Engagement without recognition: The limits of diplomatic interaction with contested states. International Affairs, 91(2), 267-285.

Kinne, B. J. (2014). Dependent diplomacy: Signaling, strategy, and prestige in the diplomatic network. International Studies Quarterly, 58(2), 247-259.

Lake, D. A. (2003). The new sovereignty in international relations. International Studies Review, 5(3), 303-323.

Özpek, B. B. (2014). The role of democracy in the recognition of de facto States: An empirical assessment. Global Governance 20(4), 585-599.

Roseberry, P. (2013). Mass violence and the recognition of Kosovo: Suffering and recognition. Europe-Asia Studies, 65(5), 857-873.

Ryngaert, C., \& Sobrie, S. (2011). Recognition of states: International law or realpolitik? The practice of recognition in the wake of Kosovo, South Ossetia, and Abkhazia. Leiden Journal of International Law, 24(2), 467-490.

Shaw, M. N. (2008). International law (6th ed.). Cambridge: Cambridge University Press.

Vidmar, J. (2009). International legal responses to Kosovo's declaration of independence. Vanderbilt Journal of Transnational Law, 42(3), 779-851.

Watson, W. K. (2008). When in the course of human events: Kosovo's independence and the law of secession. Tulane Journal of International and Comparative Law, 17, 269-274.

Wendt, A. (1999). Social theory of international politics. Cambridge: Cambridge University Press

Wilson, G. (2009). Self-determination, recognition and the problem of Kosovo. Netherlands International Law Review, 56(3), 455-481.

Worster, W. T. (2009). Law, politics, and the conception of the state in state recognition theory. Boston University International Law Journal, 27(1), 115-172. 